Original Article

\title{
ANTIBACTERIAL POTENTIAL OF ESSENTIAL OILS DERIVED FROM NATURAL, CALLUS AND IN-VITRO PROPAGATED SOURCES OF MELALEUCA ALTERNIFOLIA AGAINST COMMON BACTERIAL PATHOGENS
}

\author{
JEYAKANI M.a,c, KUMARI NIRMALA A.a, RAJALAKSHMI M.a,b*
}

aDepartment of Biotechnology and Bioinformatics, Holy Cross College (Autonomous), Tiruchirappalli 620002, Tamil Nadu, India, bDepartment of Zoology, Holy Cross College (Autonomous), Tiruchirappalli 620002, Tamil Nadu, India, cTechnical Officer, KDHP R and D Department, Munnar, Kerala 685612, India *Email: mdraji@gmail.com

Received: 27 Jan 2021, Revised and Accepted: 21 Mar 2021

\section{ABSTRACT}

Objective: Melaleuca alternifolia (M. alternifolia) and its essential oil (EO) fractions have been used widely and traditionally in the treatment of various infectious diseases and hence its antibacterial potential is investigated in the present study.

Methods: The antibacterial activity was studied through the agar disc diffusion method and broth dilution method, DNA fragmentation studies and confocal microscopy morphological studies were done. In-silico molecular interaction was studied against microbial target using docking software.

Results: The inhibitory concentration of the EOs was recorded at 75\% dilution with larger inhibition zones. The DNA fragmentation analyzed in the essential oil derived from in-vitro propagated leaves (EOIPL) of M. alternifolia treated bacterial cultures was compared with negative and positive controls. In Minimum Inhibitory Concentration (MIC) of EOIPL treated Staphylococcus aureus (S. aureus) showed time-dependent growth inhibition. The DNA content in the EOIPL treated bacterial cultures was comparatively less than in control cultures. The cell morphology changes of $S$. aureus cells were studied through confocal laser scanning microscopic analysis which showed a significant decrease in viable bacterial cells. The active component, terpinen-4-ol docked to autolysin receptor revealed stable interaction with the microbial target.

Conclusion: Thus EOIPL was explored to possess bactericidal activity against common infectious bacteria and could in incorporated in therapeutic natural antibiotic formulations as with future studies.

Keywords: M. alternifolia; EOIPL, Minimum inhibitory concentration, Terpinen-4-ol, Molecular docking

(C) 2021 The Authors. Published by Innovare Academic Sciences Pvt Ltd. This is an open access article under the CC BY license (https://creativecommons.org/licenses/by/4.0/)

DOI: https://dx.doi.org/10.22159/ijcpr.2021v13i3.42081 Journal homepage: https://innovareacademics.in/journals/index.php/ijcpr

\section{INTRODUCTION}

Since ancient times, medicinal plants have been used to maintain human healthcare [1]. Phytotherapy is a plant-based medicinal practice and the phytochemical constituents derived from these medicinal plants serve as alternative sources to synthetic drugs in treating different infections and ailments. WHO has also recommended the development and use of environment-friendly alternative methods to control diseases [2]. The phytocompounds have a history of clinical use, better patient tolerance and acceptance. Many plant extracts and essential oils isolated from plants have been shown to exert biological activity in-vitro and in-vivo, which justified research on traditional medicine focused on the characterization of antimicrobial activity of these plants [3]. Thus the development of new antibiotics depends on the strategies such as bioavailability, targeting sites, route of administration, half-life period, spectrum of resistance. Melaleuca alternifolia (M. alternifolia) commonly known as Tea tree, $M$. alternifolia belongs to the family of Myrtaceae. Tea tree oil (TTO) of $M$. alternifolia contains various mono and sesquiterpenes, aromatic compounds. The monoterpenes, terpinen-4-ol, $\gamma$-terpinene, $\alpha$ terpinene, 1,8-cineole, pcymene, $\alpha$-terpineol, $\alpha$-pinene, terpinolenes, limonene and sabinene account for $80-90 \%$ of the oil. The capabilities of the unique and demonstrated anti-bacterial, anti-fungal, anti-viral, anti-inflammatory, and anti-septic, essential oil were first scientifically documented in 1905. The TTO is considered as a universal treatment for acne, eczema, and skin infections like herpes, warts, wounds, burns, nail mycosis, insect bites, colds, sore throat, gingival infections, haemorrhoids and vaginal infections [4].

\section{MATERIALS AND METHODS}

\section{Sources of essential oils}

The essential oils (EO) used in the present study was obtained from the natural leaves, callus and in-vitro propagated leaves sources of $M$. alternifolia through steam distillation process.

\section{Quantitative estimation of EO components by GC-MS/MS}

The GC-MS/MS analysis was performed on a combined GC-MS/MS instrument (ITQ 900 Model of Thermo Fisher Scientific make) using a HP-5 fused silica gel capillary column. The method to perform the analysis was designed for both GC and MS. $1 \mu$ l aliquot of sample was injected into the column using a PTV injector whose temperature was set at $275^{\circ} \mathrm{C}$. The GC program was initiated by a column temperature set at $60^{\circ} \mathrm{C}$ for $5 \mathrm{~min}$, increased to $300^{\circ} \mathrm{C}$ at a rate of $8{ }^{\circ} \mathrm{C} / \mathrm{min}$, held for $10 \mathrm{~min}$. Helium was used as the carrier gas $(1.5 \mathrm{ml} / \mathrm{min})$. The mass spectrometer was operated in EI mode with mass source was set at $200{ }^{\circ} \mathrm{C}$. The chromatogram and spectrum of the peaks were visualized. The particular compounds present in the samples were identified by matching their mass spectral fragmentation patterns of the respective peaks in the chromatogram with those stored in the National Institute of Standards and Technology Mass Spectral database library.

\section{Antibacterial studies \\ Preparation of bacterial inoculums}

The bacteria used in this experiment were Staphylococcus aureus (S. aureus) (ATCC 43957), Escherichia coli (E. coli) (ATCC 23849), Pseudomonas aeruginosa (P. aeruginosa) (ATCC 33363), Bacillus subtilis (B. subtilis) (ATCC 21833), were procured from the Department of Clinical Microbiology, K. A. P. V. Government Medical College, Tiruchirappalli. Bacterial inoculums were prepared by sub culturing the strains under aseptic condition. A loop full of test organisms were taken and inoculated into $5 \mathrm{ml}$ of Muller Hinton Broth (MHB) and incubated at $37^{\circ} \mathrm{C}$ for 3 to $5 \mathrm{~h}$ till a moderate turbidity was developed.

\section{Agar disc diffusion method}

Antibacterial activity of the three types of EOs namely essential oil from natural leaves (EONL), essential oil from in-vitro propagated 
leaves (EOIPL), essential oil from callus (EOC) of $M$. alternifolia leaves were determined by using agar disc diffusion method. A small aliquot of the bacterial culture was swabbed over the Muller Hinton agar plates aseptically. The required sterile discs were placed on the agar medium. Using sterile tips filled with the discs in different weight percentage concentrations $(10 \%, 25 \%, 50 \%$ and $75 \%)$ of the EOs prepared and allowed to diffuse into the medium for $30 \mathrm{~min}$ at room temperature. Plates were incubated at room temperature (37 ${ }^{\circ} \mathrm{C}$ ) for $24 \mathrm{~h}$. The zone of inhibition was recorded as the mean \pm standard deviation (SD) of triplicate experiments. Tetracycline was used as reference antibiotics [5].

\section{Broth dilution method-determination of MIC}

The EOIPL was subjected to antibacterial susceptibility testing by broth microdilution method [5]. The 96-microtiter well was prepared by dispensing $45 \mu \mathrm{l}$ of Muller-Hinton broth and then a series of two-fold dilutions of each oil $(50 \mu \mathrm{l})$, ranging from $2 \%(\mathrm{v} / \mathrm{v})$ to $0.03 \%(\mathrm{v} / \mathrm{v})$, was prepared with $0.5 \%(\mathrm{v} / \mathrm{v})$ Tween-20, followed by the addition of $5 \mu \mathrm{l}$ of the $S$. aureus, E. coli, B. subtilis and $P$. aeruginosa suspensions into each well. The microtitre plate was placed in a sterile plate shaker at 300rpm for $20 \mathrm{~s}$ and then incubated at $37{ }^{\circ} \mathrm{C}$ for $24 \mathrm{~h}$. At the end of the incubation period, the plate was evaluated for the presence or absence of bacterial growth from the optical densities recorded.

\section{Statistical analysis}

All data were expressed as mean \pm SEM for control and experimental groups. The data were analyzed using one-way Analysis of Variance (ANOVA) on Statistical Package for Social Sciences (SPSS) (Version 17.0) and the group means were compared by Duncan's Multiple Range Test [6]. The results were considered statistically significant if the calculated 'p' value was less than 0.05 .

\section{DNA fragmentation analysis}

The ability of EOIPL (75\%) to cause DNA fragmentation was tested S. aureus, E. coli. $1 / 2$ MIC, MIC and 2 MIC for the tested oil was added to $10 \mathrm{ml} \mathrm{LB}$ broth containing S. aureus, E. coli, and that was incubated for $4 \mathrm{~h}$ at room temperature. One $\mathrm{ml}$ of each EOIPLbacteria combination was withdrawn and submitted to centrifugation at $10,000 \mathrm{rpm}$ for $20 \mathrm{~min}$ followed by DNA extraction. For control, genomic DNA was isolated from non-treated S. aureus, E. coli. The extracted DNA was checked for fragmentation using agarose gel electrophoresis.

\section{Cell morphological studies-confocal laser scanning microscopic analysis}

The $S$. aureus control culture and EOIPL (75\%) treated culture were prepared for CLSM analysis. One ml of MHB was taken in microcentrifuge tubes inoculated with both bacterial cultures separately and then $30 \mu \mathrm{l}$ of the EO was added to each of the tube and incubated overnight at $37^{\circ} \mathrm{C}$. Tetracycline $(30 \mu \mathrm{g} / \mathrm{ml})$ treated bacterial cultures were taken as positive control. 0.1\% Acridine orange (AO) stain was prepared and $10 \mu \mathrm{l}$ of $\mathrm{AO}$ stain was added to each tube and incubated for $30 \mathrm{sec}$. The tubes were then centrifuged to collect the pellets. The pellets were washed with water twice and air-dried. The stained bacterial cultures were smeared on the glass slides. On viewing under the microscope $15 \%$ glycerol was added to the thin smear and covered with a coverslip [7].

\section{In-silico analysis}

The exact interaction of the compound with the microbial target was analyzed using in-silico molecular docking analysis.

\section{Molecular docking}

The structure of Autolysin (PDB id- 2B0P) was retrieved from the Protein Data Bank (PDB) in. pdb text format [8]. The 3D structures of terpinen-4-ol were developed using ACD/ChemSketch software. In molecular docking, the software allows us to virtually screen a database of compounds and predict the strongest binders based on various scoring functions. It explores the ways in which the molecules and the receptors fit together and dock to each other well. Thus docking analysis of the terpinen-4-ol with Autolysin was carried out by Libdock module of Discovery studio (Version 2.1, Accelry's Software Inc.), a licensed life science modeling and simulation suite of application focused on optimizing the drug discovery process by identifying the specific amino acid residues to which the compound fitted together.

\section{RESULTS}

\section{Essential oil extraction}

The EOs were extracted from all three sources of M. alternifolia (natural leaves, callus and in-vitro propagated leaves) through the steam distillation process and the oil content was comparatively analyzed. The results tabulated (table 1) showed that, the maximum level of oil recovery was obtained in in-vitro propagated leaves of about $3.79 \mathrm{ml}$ and the influence of moisture was $10.34 \%$.

Table 1: Essential oil extraction from natural leaves, callus and in-vitro propagated leaves of $M$. alternifolia

\begin{tabular}{|c|c|c|c|c|c|}
\hline \multicolumn{3}{|c|}{ Steam distillation } & \multirow{2}{*}{$\begin{array}{l}\text { Natural leaves } \\
\text { Oil volume }(\mathrm{ml})\end{array}$} & \multirow{2}{*}{$\begin{array}{l}\text { Callus } \\
\text { Oil volume }(\mathrm{ml})\end{array}$} & \multirow{2}{*}{$\begin{array}{l}\text { In-vitro propagated leaves } \\
\text { Oil volume }(\mathrm{ml})\end{array}$} \\
\hline $\begin{array}{l}\text { Raw material } \\
\text { input }(\mathrm{g})\end{array}$ & $\begin{array}{l}\text { Vapour seed } \\
(\mathrm{g} / \mathrm{h})\end{array}$ & $\begin{array}{l}\text { Time extract } \\
\text { (min) }\end{array}$ & & & \\
\hline 100 & 200 & 200 & 1.4 & 1.5 & 1.64 \\
\hline 100 & 200 & 250 & 1.4 & 1.9 & 2.2 \\
\hline 100 & 200 & 300 & 2.4 & 2.5 & 2.79 \\
\hline 100 & 200 & 350 & 2.6 & 2.8 & 3.4 \\
\hline 100 & 200 & 400 & 3.12 & 3.3 & 3.79 \\
\hline
\end{tabular}

Table 2: Component analysis of EONL, EOIPL and EOC derived from M. alternifolia through GC-MS/MS analysis

\begin{tabular}{lllll}
\hline S. No. & Component & Max $\%$ & EONL & EOC \\
\hline 1 & Terpine-4-ol & $30-48$ & 32.32 & 33.01 \\
2 & y-terpinene & $10-28$ & 12.5 & 12.8 \\
3 & $\alpha$-terpinene & $5-13$ & 5 & 5.43 \\
4 & $1-8$-cineole & $0-15$ & 8.9 & 9.98 \\
5 & Terpinoeol & $1.5-5$ & 1.73 & 1.8 \\
6 & $\alpha$-terpineol & $1.5-8$ & 3.46 & 3.53 \\
7 & $\alpha$-pinene & $1-6$ & 2.34 & 3.11 \\
8 & p-cymene & $0.5-8$ & 3.8 & 4.7 \\
9 & Limonene & $0.5-1.50$ & 0.52 & 4.5 \\
\hline
\end{tabular}

\section{GC-MS/MS}

The GC-MS/MS performed on EONL, EOIPL and EOC reported the presence of 9 major components (fig. 1a-1c). These components were found to be in abundance and the nature of them was identified with the peaks obtained in the GC graph in comparison to the library of compounds. The library search confirmed the presence of compounds such as limonene, $\alpha$-pinene, $\alpha$-terpinene, $p$-cymeme, 
1,8-cineole, terpinene, $\alpha$-terpinolene, terpinen-4-ol, and terpineol. The maximum percentages of the components obtained in the essential
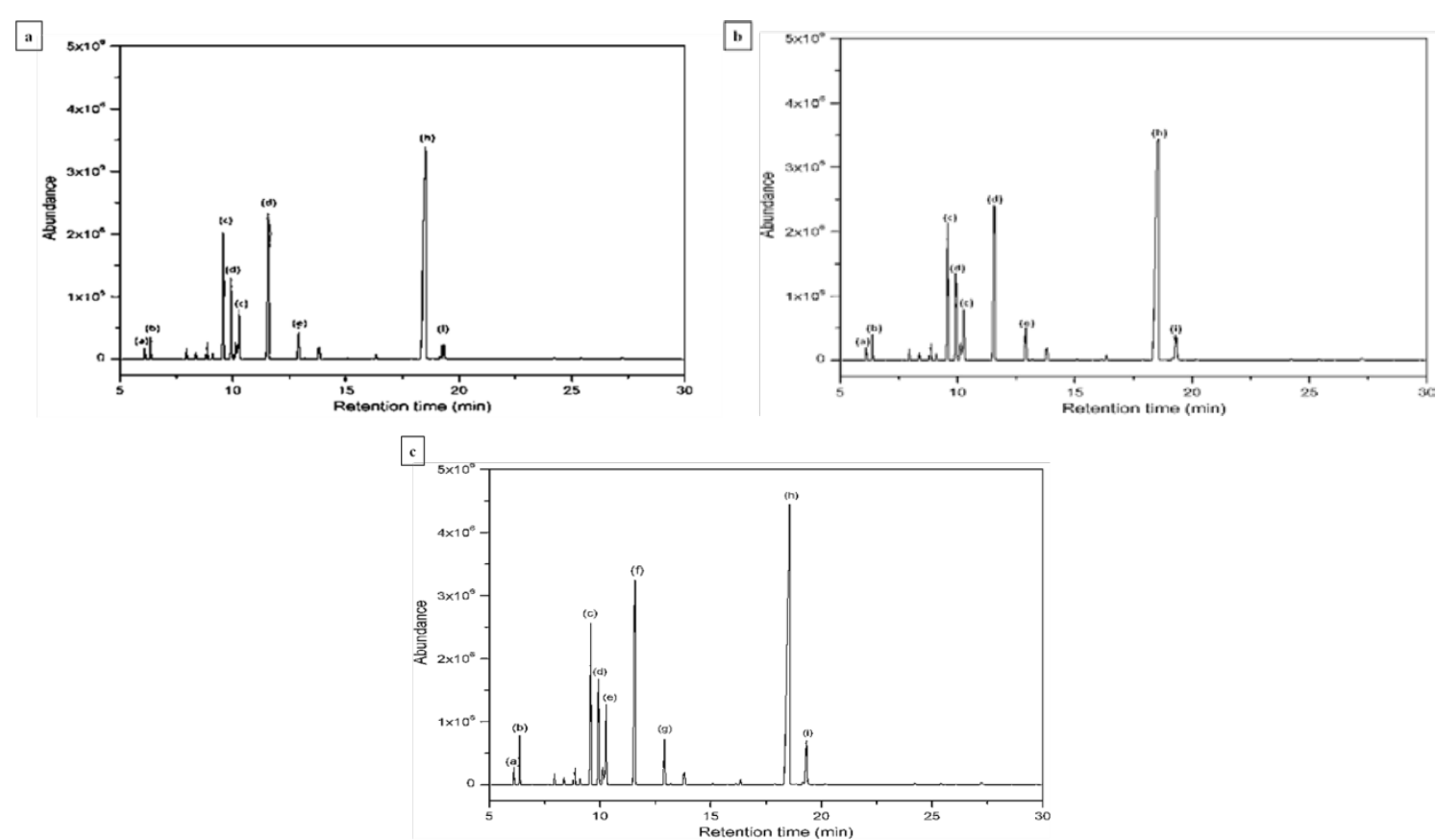

Fig. 1a-1c: Chromatograms of the EONL, EOC and EOIPL derived from M. alternifolia. The GC graph indicates the presence of nine major compounds (a) limonene, (b) $\alpha$-pinene, (c) 1,8-cineole, (d) $\alpha$-terpinene, (e) p-cymene, (f) $\gamma$-terpinene, (g) $\alpha$-terpineol, (h) terpinen-4-ol, (i) $\alpha$-terpinolene

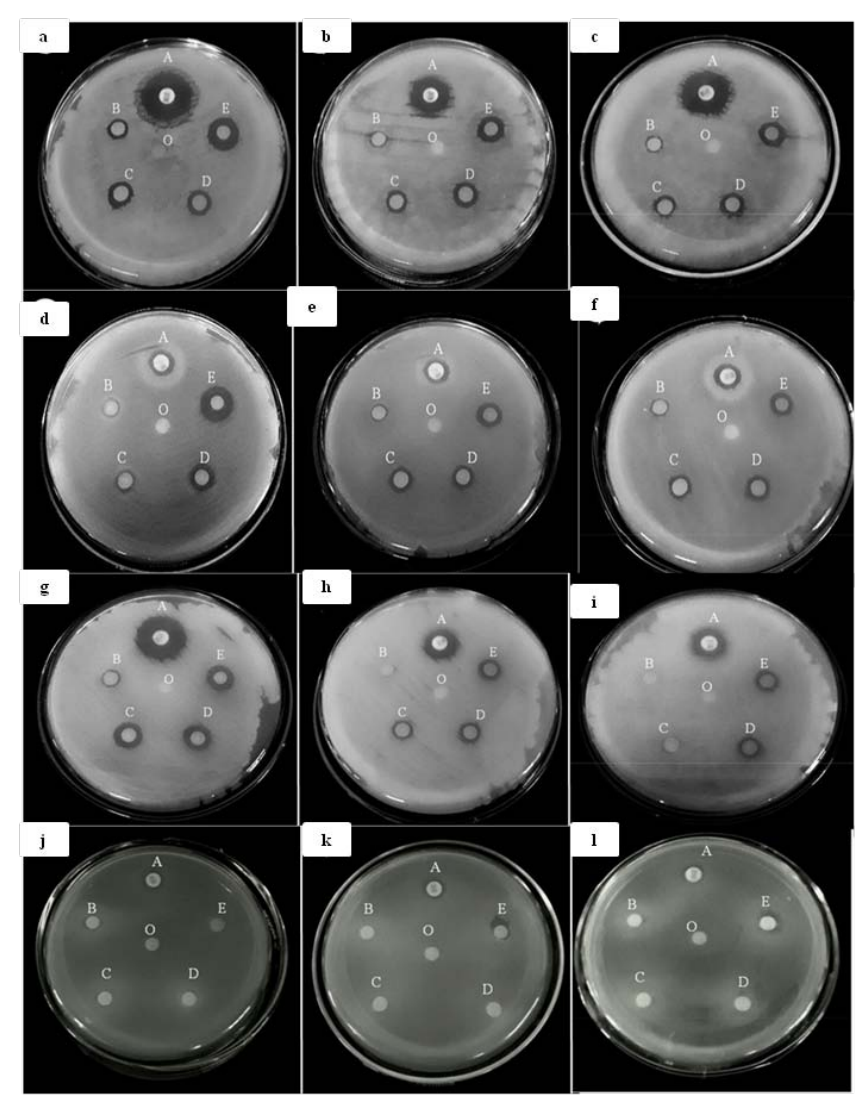

Fig. 2: Antibacterial activity of essential oils a) EONL against E. coli, b) EOIPL against E. coli, c) EOC against E. coli, d) EONL against $S$. aureus, e) EOIPL against $S$. aureus, f) EOC against $S$. aureus, g) EONL against $B$. subtilis, h) EOIPL against $B$. subtilis, i) EOC against $B$. subtilis, j) EONL against $P$. aeruginosa, k) EOIPL against $P$. aeruginosa, l) EOC against $P$. aeruginosa. A- Tetracycline (30 $\mu \mathrm{g}), \mathrm{B}-10 \%$ EO, C- 25\% E0, D-50\% EO, E-75\% E0, 0-Control 


\section{Determination of zone of inhibition}

The antimicrobial activity of EONL, EOC and EOIPL of $M$. alternifolia at varying concentrations $(10 \%, 25 \%, 50 \%, 75 \%)$ was compared with a standard antibiotic drug, tetracycline $(30 \mu \mathrm{g} / \mathrm{ml})$ against $E$. coli, S. aureus, B. subtilis, and P. aeruginosa. Among these concentrations from all the above three sources, $75 \%$ of EOs produced a clear zones around the discs (fig. 2) and are comparatively similar to antibiotic drug (Tetracycline $(30 \mu \mathrm{g} / \mathrm{ml}$ ). The zone of inhibition diameters were ranged from 2 to $6.5 \mathrm{~mm}, 2$ to $7 \mathrm{~mm}, 0.5$ to $6 \mathrm{~mm}$ and 0.5 to $3.5 \mathrm{~mm}$ for E. coli, S. aureus, B. subtilis, and $P$. aeruginosa respectively (table 3 ).

Table 3: Antibacterial activity of EONL, EOIPL and EOC obtained from M. alternifolia against bacterial pathogens

\begin{tabular}{|c|c|c|c|c|c|}
\hline \multirow{2}{*}{$\begin{array}{l}\text { Source of } \\
\text { essential oil }\end{array}$} & \multirow{2}{*}{$\begin{array}{l}\text { Concentration of essential } \\
\text { oil (in weight percentage) }\end{array}$} & \multicolumn{4}{|c|}{ Bacterial pathogens } \\
\hline & & S. aureus & E. coli & B. subtilis & P. aeruginosa \\
\hline \multirow[t]{5}{*}{ EONL } & $10 \%$ & $2 \pm 0.29$ & $3 \pm 0.29$ & $3 \pm 0.33$ & $0.5 \pm 0.29$ \\
\hline & $25 \%$ & $3 \pm 0.29$ & $4 \pm 0.5$ & $4.5 \pm 0.29$ & $1 \pm 0.5$ \\
\hline & $50 \%$ & $5 \pm 0.33$ & $5 \pm 0.33$ & $5 \pm 0.29$ & $1 \pm 0.33$ \\
\hline & $75 \%$ & $7 \pm 0.29$ & $6.5 \pm 0.29$ & $6 \pm 0.33$ & $1 \pm 0.33$ \\
\hline & Tetracycline & $5 \pm 0$ & $12 \pm 0$ & $10 \pm 0$ & $8 \pm 0$ \\
\hline \multirow[t]{5}{*}{ EOIPL } & $10 \%$ & $2 \pm 0.33$ & $2 \pm 0.29$ & $1.5 \pm 0.29$ & $1 \pm 0.29$ \\
\hline & $25 \%$ & $3 \pm 0.29$ & $3.5 \pm 0.33$ & $2.5 \pm 0.29$ & $1.5 \pm 0.29$ \\
\hline & $50 \%$ & $4 \pm 0.29$ & $5 \pm 0.29$ & $3.5 \pm 0.29$ & $2 \pm 0.33$ \\
\hline & $75 \%$ & $5.5 \pm 0.29$ & $6 \pm 0.33$ & $4.5 \pm 0.33$ & $3 \pm 0.33$ \\
\hline & Tetracycline & $5 \pm 0$ & $12 \pm 0$ & $10 \pm 0$ & $8 \pm 0$ \\
\hline \multirow[t]{5}{*}{ EOC } & $10 \%$ & $2 \pm 0.29$ & $2 \pm 0.29$ & $0.5 \pm 0.29$ & $2 \pm 0.29$ \\
\hline & $25 \%$ & $3 \pm 0.29$ & $3 \pm 0.33$ & $1 \pm 0.5$ & $3 \pm 0.29$ \\
\hline & $50 \%$ & $4 \pm 0.33$ & $4.5 \pm 0.33$ & $1.5 \pm 0.5$ & $3 \pm 0.29$ \\
\hline & $75 \%$ & $5 \pm 0.33$ & $5 \pm 0.29$ & $3 \pm 0.29$ & $3.5 \pm 0.29$ \\
\hline & Tetracycline & $5 \pm 0$ & $12 \pm 0$ & $10 \pm 0$ & $8 \pm 0$ \\
\hline
\end{tabular}

*Each value represents mean \pm SD done in triplicates.

\section{Determination of minimum inhibitory concentration}

In order to estimate the susceptibility of the bacteria towards EOIPL, the broth dilution method was carried out in two-fold dilution EOIPL treated bacterial culture showed better results with an MIC value of $75 \times 2^{-2} \%$ (i. e. $18.75 \%$ ) essential oil. The results also showed that maximum dilution of the sample produced least inhibition on bacterial growth or vice-versa an exponential increase in the bacterial population (fig. 3).

\section{EOIPL-induced DNA fragmentation}

The bacterial cultures were treated with the standard concentration (75\%) of EOIPL and the subsequent change in the DNA pattern due to the induction of DNA fragmentation upon EO treatment for $24 \mathrm{~h}$ was analyzed through agarose gel electrophoresis. The DNA patterns of the EOIPL treated E. coli and S. aureus cultures showed a significant decrease in the total DNA content in comparison to their untreated control cultures respectively (fig. 4) and hence the EO treatment could have inhibited the DNA synthesis in the bacterial cells.

Determination of bacterial cell death and morphological changes by confocal laser scanning microscopy

The standard concentration (75\%) of EOIPL treated S. aureus culture was subjected to confocal laser scanning microscopic analysis in order to study the changes in the cell morphology. The confocal laser scanning microscopic images showed the absence of viable cells and disrupted cell structures in essential oil treated $S$. aureus culture (fig. 5) which was similar to the result obtained with standard antibiotic drug, tetracycline $(30 \mu \mathrm{g} / \mathrm{ml})$ treatment.

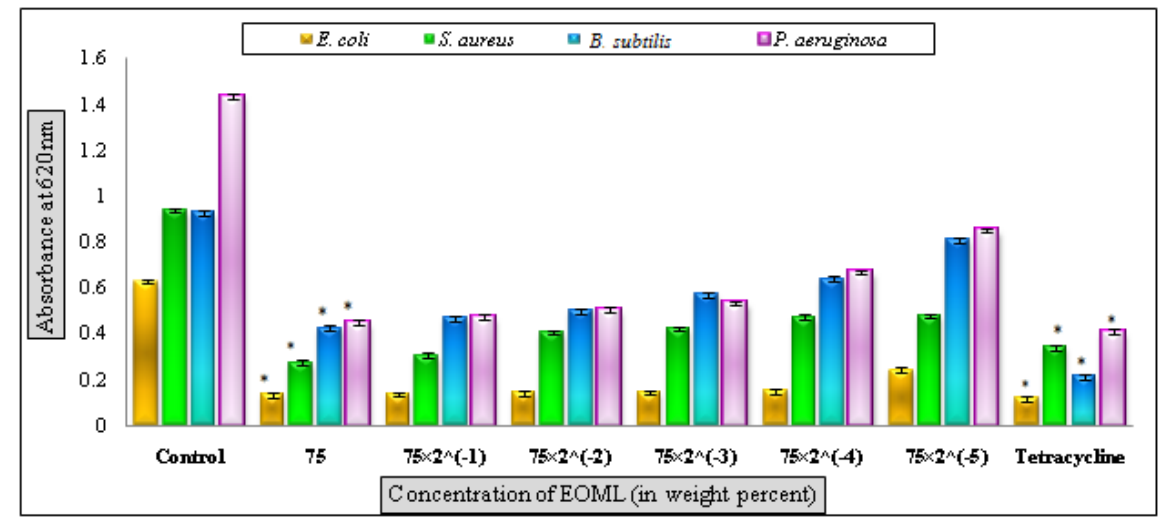

Fig. 3: Minimum inhibitory concentration for the EOIPL of $M$. alternifolia against bacterial pathogens. Each value is mean \pm SEM of three independent observations. ' ${ }^{* \prime}$ represents statistical significance between control versus essential oil-treated organisms at $p<0.05$

\section{Molecular docking}

Docking studies were performed by accelrys discovery studio 2.1 to find the possible binding site of Autolysin. From the binding site analysis, the binding pockets were identified and the largest binding pocket was selected as active site for the docking studies. The protein was docked with terpinen-4-ol (fig. 6), an important component present in the EO mixture and its corresponding Libdock score was calculated. The docking result proved that terpinen-4-ol showed the conventional hydrogen bond interactions (table 4) within active site at the amino acid residues ASN 286 and HIS 260 (fig. 7). 


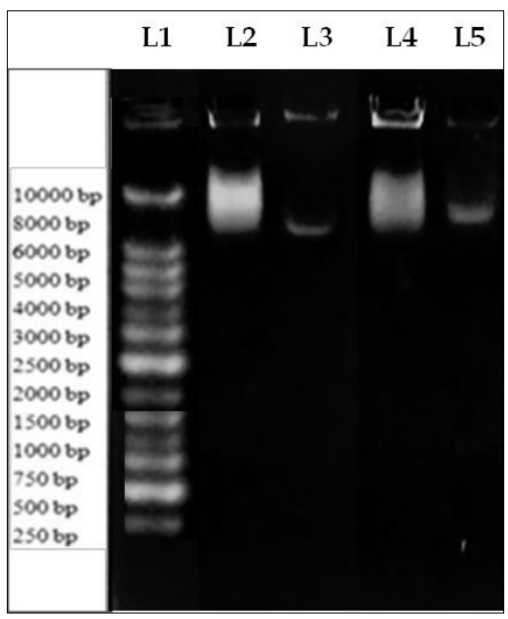

Fig. 4: EOIPL induced-DNA fragmentation in E. coli and S. aureus. Lane 1- Molecular weight marker; Lane 2- E. coli Control; Lane 3- E. coli treated with EOIPL; Lane 4- S. aureus Control; Lane 5- S. aureus treated with EOIPL
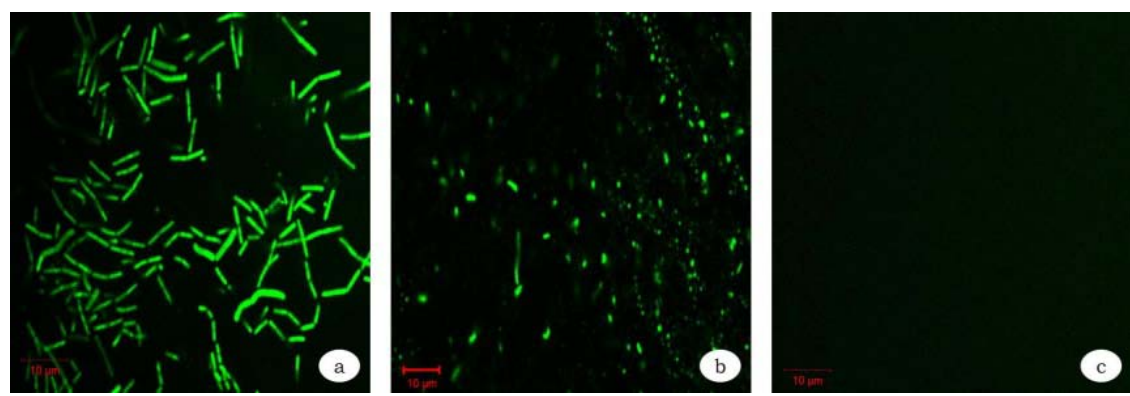

Fig. 5: EOIPL induced-cell death in S. aureus a-S. aureus Control, b- $S$. aureus treated with EOIPL, c- $S$. aureus treated with tetracycline $(30 \mu \mathrm{g} / \mathrm{ml})$
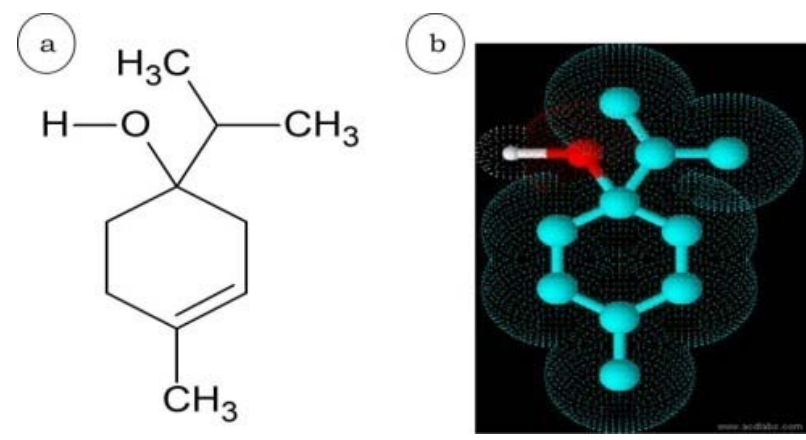

Fig. 6: 2a-Two-dimensional structure of terpinen-4-ol, b-Three-dimensional structure of terpinen-4-ol

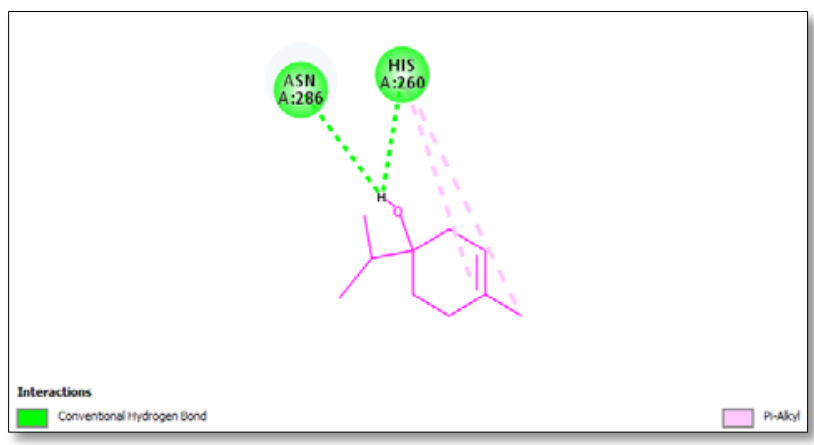

Fig. 7: Receptor- ligand interaction analysis through molecular docking studies, terpinen-4-ol interacted with autolysin with hydrogen bond interactions (green dotted lines) 
Table 4: Interaction analysis of receptor-ligand complex

\begin{tabular}{|c|c|c|c|c|c|c|c|c|}
\hline Compound & Target protein & PDB ID & $\begin{array}{l}\text { No. of } \\
\text { poses }\end{array}$ & $\begin{array}{l}\text { Absolute } \\
\text { energy }\end{array}$ & $\begin{array}{l}\text { Libdock } \\
\text { score }\end{array}$ & $\begin{array}{l}\text { No. of H- } \\
\text { bond }\end{array}$ & Residues & $\begin{array}{l}\text { Bond } \\
\text { length }(\AA)\end{array}$ \\
\hline Terpine-4-ol & Autolysin & $2 \mathrm{~B} 0 \mathrm{P}$ & 99 & 18.318 & 59.44 & 2 & $\begin{array}{l}\text { Asn286 } \\
\text { His260 }\end{array}$ & $\begin{array}{l}2.3686 \\
2.2266\end{array}$ \\
\hline
\end{tabular}

\section{DISCUSSION}

In order to treat drug-resistant bacteria, there must be new arrival of alternative strategies in drug to deal with infectious disease caused by antibiotic-resistant bacteria. Nowadays many authors have been found that various phytochemicals present in the herbal medicinal plants that could be able to treat such infections with good bactericidal effects. Plant derived essential oils have the ability to penetrate the skin and pass into the blood that showed a good synergistic effect of EOs. Most of the essential oils available today are extracted by steam distillation process as it causes minimum changes to the essential oil composition during extraction. Lee et al. (2013) has reported that TTO that comes from M. alternifolia leaves contains over 100 components (mostly monoterpenes, sesquiterpenes and terpene alcohols [9]. Studies demonstrated that terpinen-4-ol, a monoterpene is the most abundant (minimum 30\%) component, besides this TTO also contains various amounts of 1, 8-cineole that causes skin irritant [10]. In this study the EOs from M. alternifolia showed best results in the treatment of skin infections ( $E$. coli and $S$. aureus) as well as respiratory disease (B. subtilis and P. aeruginosa) causing bacteria. When compared with other bacteria, $S$. aureus was highly susceptible to EOIPL of $M$. alternifolia with larger inhibition zone whereas in $E$. coli showed less inhibition zone due to the presence of lipoproteins and lipopolysaccharides in their cellular walls that form a barrier to hydrophobic compounds. The EOIPL exhibited maximum inhibitory activity against the bacteria due to higher content of secondary metabolites in it. In MIC, the standard concentration (75\%) of EOIPL disrupts the permeability barrier of cell membrane structures at the exponential growth stage of the cell and [11] the accompanying loss of chemiosmotic control is the most likely source of its lethal action at minimum inhibitory levels. Genomic DNA fragmentation is the indicator of cell death achieved by the activation endonucleases causing nicks in the DNA strands. This activity of the antibacterial reduces the replication of DNA. In the present study, the EOIPL induced DNA fragmentation in both $E$. coli and $S$. aureus cells, which might be due to the activation of endonucleases and disturbance in the hydrogen bonding involved in the stacking of nucleic acid bases and inhibition of DNA gyrase activity involved in unwinding of super coiled DNA through ATPase inhibition. The presence of glycosides, flavonoids and also phenolic and non-phenolic compounds present in the essential oil might induce the DNA cleavage in whole cells [12]. The standard concentration (75\%) of EOIPL treated S. aureus culture was subjected to CLSM analysis that affected the cell viability by losing the ability to regulate potassium transfer across the membrane that leads to an outpouring of potassium interaction with from the cell [13]. Generally in bacteria the stress signals are sensed by the membranebound signal transduction system and hence disturbance caused in the membrane integrity is the measure of cytotoxicity of an antibacterial drug [14]. In accordance with these reports, our results from CLSM images showed that the EO derived from the in-vitro propagated leaves of $M$. alternifolia inhibited the growth $S$. aureus and also damaged the cell structural morphology, wherein decreased viable cells were observed. It has been suggested that terpenes promote membrane disruption binding to polysaccharides or enzymes promoting inactivation $[15,16]$. Docking pattern was reliable with stability of the complex evaluated from its absolute energy [17] and also showed a firm interaction of hydrogen bond length being less than $3 \AA$ RMSD [18]. The mechanism of action of terpinen-4-ol causes the release of membrane bound cell wall autolytic enzymes will induce lysis eventually. The activation of autolytic enzymes may have been due to weakening of the cellwall and the subsequent rupture of the cytoplasmic membrane due to osmotic pressure [19].

\section{CONCLUSION}

Thus the study revealed the significance of the EOIPL derived from $M$. alternifolia leaves as a potential antibacterial agent and further investigation in this aspect could help in exploring their mode of action as well as the pathway in which it interacts with the target (receptor) proteins it in order to bring about bacteriostatic and bactericidal effect.

\section{ACKNOWLEDGEMENT}

My sincere thanks to DBT-BIF Centre, Holy Cross College (Autonomous), Tiruchirappalli, TamilNadu, India, for providing facility to carry out docking studies.

\section{FUNDING}

Nil

\section{AUTHORS CONTRIBUTIONS}

Ms. Jeyakani did all the experimental work and manuscript writing. Ms. Kumari Niirmala did molecular docking studies and manuscript editing. Dr. Rajalakshmi did research guidance and critical revision of manuscript.

\section{CONFLICT OF INTERESTS}

The authors declare that they have no conflict of interest.

\section{REFERENCES}

1. Capasso R, Izzo AA, Pinto L, Bifulco T, Vitobello C, Mascolo N. Phytotherapy and quality of herbal medicines. Fitoterapia 2000;71:58-65.

2. Mamta, Jakhar KK. Studies on in-vitro antibacterial activity of Tinospora cordifolia stem extract on Escherichia coli. Vet Res Int 2016;4:74-7.

3. Snoussi M, Hajlaoui H, Noumi E, Zanetti S, Bakhrouf A. Phenotypic and genetic diversity of Vibrio alginolyticus strains recovered from juveniles and older Sparus aurata reared in a Tunisian marine farm. Ann Microbiol 2008;58:141-6.

4. Carson CF, Hammer KA, Riley TV. Melaleuca alternifolia (Tea Tree) Oil: a Review of antimicrobial and other medicinal properties. Clin Microbiol Rev 2006;19:50-62.

5. Melvin P. Weinstein, MD. Performance standards for antimicrobial susceptibility testing. NCCLS Document 2002(Suppl 12);100-12.

6. Duncan BD. Multiple range tests for correlated and heteroscedastic means. Biom 1957;13:164-7.

7. Cerca N, Gomes F, Pereira S, Teixeira P, Oliveira R. Confocal laser scanning microscopy analysis of Streptococcus epidermidis biofilms exposed to farnesol, vancomycin and rifampicin. BMC Res Notes 2012;5:244.

8. Berman HM, Westbrook J, Feng Z, Gilliland G, Bhat TN, Weissig $\mathrm{H}$, et al. The protein data bank. Nucleic Acids Res 2000;28:235-42.

9. Daisy P, Eliza J, Ignacimuthu S. Influence of Costus speciosus (Koen.) $\mathrm{Sm}$. rhizome extracts on biochemical parameters in streptozotocin induced diabetic rats. J Health Sci 2008;54:675-81.

10. Lee $\mathrm{C}$, Chen $\mathrm{L}$, Chen $\mathrm{L}$, Chang $\mathrm{T}$, Huang $\mathrm{C}$, Huang $\mathrm{M}$, et al. Correlations of the components of tea tree oil with its antibacterial effects and skin irritation.J Food Drug Anal 2013;21:169-76.

11. Calcabrini A, Stringaro A, Toccacieli L, Meschini S, Marra M, Colone $\mathrm{M}$, et al. Terpinen-4-ol, the main component of Melaleuca alternifolia (tea tree) oil inhibits the invitro growth of human melanoma cells. J Invest Dermatol 2004;122:349-60.

12. Jakub K, Sigrun E, Kinga W. Effects of tea tree (Melaleuca alternifolia) oil on Staphylococcus aureus in biofilms and stationary growth phase. Int J Antimicrob Agents 2009;33:343-7.

13. El-Tablawy SY, Araby E. Impact of marjoram (Origanum marjorana L.) essential oil on some virulence factors and 
DNA integrity of multidrug resistant Klebsiella pneumoniae. IOSR J Pharm Biol Sci 2017;12:63-71.

14. Corliss AO, Sean JP, Philip GC. Steven CR. Potential of plant essential oils and their components in animal agriculture-invitro studies on antibacterial mode of action. Front Vet Sci 2015;2:197-9.

15. Reck M, Rutz K, Kunze B, Tomasch J, Surapaneni S, Schulz S, Wagner Dobler I. The biofilm inhibitor carolacton disturbs membrane integrity and cell division of streptococcus mutans through the serine/threonine protein kinase PknB. J Bacteriol 2011;193:5692-706.
16. Ya C, Gaffney SH, Lilley TH, Haslam E. Carbohydrate-polyphenol complexation. In: Hemingway RW, Karchesy JJ. eds. Chemi and signify of conden. Tan. New York, NY: Plenum Press; 1988. p. 553.

17. Cowan MM. Plant products as antimicrobial agents. Clin Microbiol Rev 1999;12:564-82.

18. Daisy P, Suveena S, Lilly VJ. Molecular docking of medicinal compound Lupeol with autolysin and potential drug target of UTI. J Chem Pharm Res 2011;3:557-62.

19. Daisy P, Vijayalakshmi P, Selvaraj C, Singh SK, Saipriya K. Targeting multidrug resistant mycobacterium tuberculosis HtrA2 with Identical chemical entities of fluoroquinolones. Indian J Pharm Sci 2012;74:217-22. 